to see the world in ways that make it virtually impossible not to believe them." Lieberman thinks that East Asian cultures stress interconnectedness among individuals, whereas Western Europeans tend to be more independent. He suggests that this tendency might be genetically influenced by a serotonin transporter gene, found twice in its 'short' variant in two-thirds of East Asians, but in only one-fifth of Western Europeans. "These cultural Big Ideas appear to have migrated until they found the populations with the right neurochemistry to make them sticky," Lieberman says.

Psychologist Lera Boroditsky asks how language influences the way we think: "People who speak different languages do indeed think differently and ... even flukes of grammar (such as the particular gender assigned to a noun in different languages) can profoundly affect how we see the world."

Modern science is highly specialized, but many scientists agree that interdisciplinary research is crucial to future work. Climatologist Gavin Schmidt asks why specialization has not led to the complete Balkanization of science, remarking that "It has been suggested that the physicist, physician, and Egyptologist Thomas Young (1773-1829) was the last person to 'know everything."' Schmidt seeks to distinguish between those fields that are separate out of necessity, and those that are mere artefacts of the way we organize our institutions. Fields become established because "the older, pioneering generation wants to employ and promote successors in its own mold; the younger generation wants to emulate its mentors", he says. But then "jargon excludes most of those outside the subfield". Schmidt warns us of the barriers that will have to be broken down, but he does not provide a good solution for doing so.

What Next? covers other ground, including global climate change, virus metagenomics, dark matter, entropy, the perception of time and the question of what makes us human. But there is surprisingly little coverage of computing or computational biology, engineering, space travel and colonization, personalized medicine, biotechnology, stem-cell biology, human cloning or artificial intelligence. The authorship is biased toward US male psychologists, and other voices might have broadened the perspective. Ideally, the book should have been twice the size, laden with references and with less repetition, and really pushing the edge. Scientists must not leave the future entirely in the hands of science-fiction writers.

Michael A. Goldman is professor and chair of

the Department of Biology at San Francisco State University, California 94132-1722, USA.

e-mail: goldman@sfsu.edu

\title{
Galileo and the Pope
}

\section{Two Men of Florence \\ by Richard N. Goodwin \\ Huntington Theatre, Boston, Massachusetts 6 March to 5 April 2009}

Richard Goodwin's engrossing, witty and moving - if somewhat ahistorical - play about Galileo Galilei and Pope Urban VIII recently completed a run in Boston, Massachusetts, with a fine production mounted by the Huntington Theatre Company. Significantly reworked since its original production in 2003, Two Men of Florence deserves to become a classic.

Goodwin retains a reference to the title of his earlier version, The Hinge of the World, which plays on the alternative meaning of 'hinge' as 'cardinal. Having completed the masterpiece that will destroy his standing with the Catholic Church, Galileo says to his daughter, "You and I, Maria, the saint and the philosopher, together we lean on the hinge of the world." Goodwin's depiction of their relationship, a role enhanced since the earlier production, deviates from the historical one that Dava Sobel described so compellingly in her 1999 book Galileo's Daughter.

Far from the play's portrayal of Maria as an essential collaborator in her father's work, the real Maria Celeste was placed in a convent at the age of 13 , where she served as an apothecary. Although she read her father's books and letters, her assistance was limited to supplying him with medications and moral support. Galileo drew comfort from her letters as he endured his confrontation with the Inquisition and the Pope in 1633, following the publication of his controversial work 'Dialogo'.

Goodwin's new title for the play focuses the audience's expectations more properly on the complicated relationship between Galileo the scientist and Urban the cleric. Both native Tuscans, they discover that they are intellectual compatriots. Galileo recognizes Urban as "a philosopher", an identification that Urban accepts with a slight modification: "Not a philosopher, Galileo, but at least a man of Florence, one who understands that the light of philosophy can enhance the radiance of faith." The Boston production was well served by the two actors in the starring roles: Edward Herrmann as Cardinal Maffeo Barberini, later Pope Urban VIII, and Jay O. Sanders as Galileo.

In Goodwin's rendering, the Pope encourages Galileo to write a "discussion between the followers of Copernicus and the supporters of Aristotle, a dialogue which contains

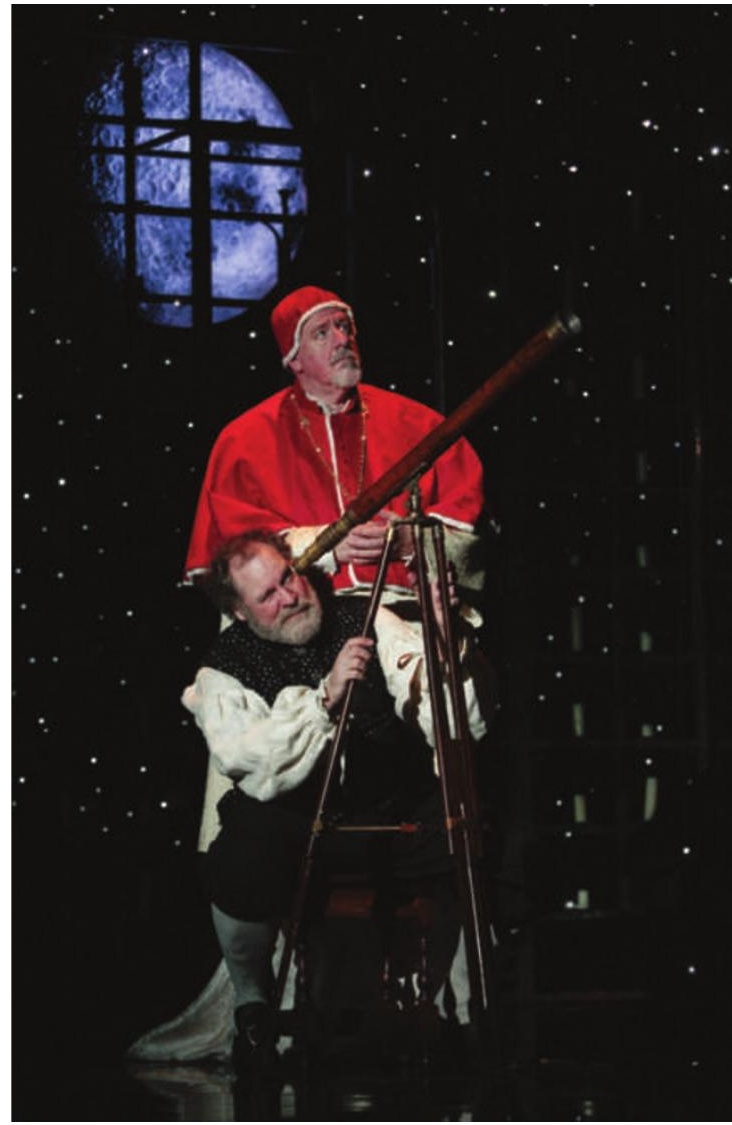

Richard Goodwin's play explores the personal interactions between Galileo and Pope Urban VIII.

arguments of all schools, in language which every educated man will comprehend". When Galileo tells Urban that his working title is On the Flux and Reflux of the Tides, the Pope advises him otherwise: "Since it is a dialogue, why not call it such - A Dialogue on the Two Great World Systems." Although renaming the book was a requirement of the Inquisition, it was dramatic licence to make it the suggestion of the Pope himself.

Both are men of towering ambition, and each ultimately feels betrayed by the other. After reading Galileo's pro-Copernican magnum opus, the Pope complains. He had, he thought, received a promise that the book would give equal treatment to each side, Copernican and Ptolemaic: "He deceived me. He betrayed his word. He makes a joke of Christianity." When Galileo learns that as a result of what he has written he will be under house arrest and his works banned, the scientist says, "This was never discussed. Never agreed."

In 1992, Pope John Paul II said, although falling short of an apology, "A tragic mutual 
incomprehension has been interpreted as the reflection of a fundamental opposition between science and faith." Goodwin's Galileo refers to this mutual incomprehension when he tells Urban, "I thought you understood, but you do not understand. My philosophy rests on faith. I have been gifted by God to understand some of the language of His creation."

Goodwin beautifully dramatizes the two men's inability to reconcile by using on stage a piece of scientific equipment. Galileo demonstrates his occhiale - a compound microscope, a modification of his telescope to the delighted Pope. Several scenes and many years later, the Pope picks up the same occhiale to let the scientist examine a communion wafer under its lens. Although Galileo admits he sees only an uneven surface, resembling that of the Moon, he accepts on faith the wafer as the body of Christ. The Pope accuses Galileo of being a heretic, "one who misreads the faith", and "the creator of a whole new faith whose trinity is the eyes ... the mouth ... and the brain".

Goodwin's earlier career as a speech writer for US presidents John F. Kennedy and Lyndon Johnson has clearly familiarized him with the loneliness of political leaders. At the end of the play, it is the victorious Pope who is more bereft than Galileo. Compelled by the responsibility of his office, Urban has jettisoned not only Galileo but also his own oldest friend, Monsignor Giovanni Ciampoli, who, as secretary of the briefs, gave Galileo "the licence to unloose his pestilential work on enfeebled Europe". Urban banishes Ciampoli to a remote village.

Galileo, deprived of the companionship of his daughter who has predeceased him, is joined in the final scene by Father Benedetto Castelli, a former student of Galileo and now a professor. Castelli's return restores hope to his former teacher, whose forced recantation has left him wondering: "How shall I continue - my proclamations of new wonders returned only by mocking echoes from the indifferent hills of Tuscany." As the two men set off for Arcetri, near Florence, where Galileo will be confined for the rest of his life, the older man tells his disciple, "Let us go home. There is much for us to do."

Throughout the play, the language and stage business were enhanced through the motifs of burning, revolution and rotation. The powerful opening scene depicts philosopher Giordano Bruno being burned at the stake in Rome's Campo dei Fiori in 1600 for heresy. Later, Maria burns Galileo's papers, as per her father's request. Goodwin used large, horizontally rotating devices on stage to demonstrate some of Galileo's scientific insights to great effect.

Following its brilliant run in Boston, Two Men of Florence deserves to find its place as a standard in the growing repertoire of plays dealing with science and scientists, including Bertolt Brecht's Life of Galileo and Michael Frayn's Copenhagen.

Jay M. Pasachoff is director of the Hopkins Observatory, Williams College; Naomi Pasachoff is a research associate at Williams College, Williamstown, Massachusetts 01267, USA. e-mail: jay.m.pasachoff@williams.edu; naomi.pasachoff@williams.edu

\section{Smells like green spirit}

\section{Green Aria: A ScentOpera \\ The Peter B. Lewis Theater, Guggenheim Museum, New York City \\ 31 May and 1 June 2009}

Audience members attending Green Aria, which has its world premiere at the Guggenheim Museum in New York this week, can leave their opera glasses at home. The brainchild of director and librettist Stewart Matthew, this aria will be performed in the dark. But while the eyes get a rest, the nose will be hard at work. Green Aria is a scent opera, a performance involving synchronized sounds and smells.

Each of the roughly two dozen characters in this musical tale about humanity's attempt to tame nature will have a distinct odour, transmitted for a few seconds at a time through a 'scent speaker' attached to each auditorium chair. The opera will tap into two perceptual pathways in the brain simultaneously.

"There have been other attempts to introduce smell technology in conjunction with various forms of art and entertainment," explains Matthew. But it is little used today. In 1960, a system called Smell-O-Vision released timed scents in a cinema to match the scenes unfolding in a film. And a 1981 movie by John Waters, Polyester, prompted audiences to use scratch-and-sniff Odorama cards at particular points in the plot.

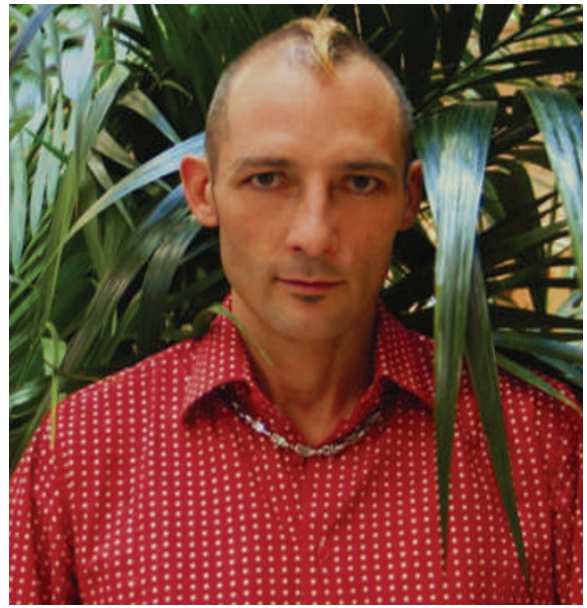

Perfume perfectionist Christophe Laudamiel.

In the Guggenheim Museum's theatre, special tubing will connect the scent speakers on the chairs to a customized 'odour organ' jointly developed by Fläkt Woods, a company specializing in air-circulation systems, and Aeosphere, a fragrance media company. Aeosphere is headed by Matthew and fragrance designer Christophe Laudamiel, who created the opera's scents.

Laudamiel holds a master's degree in chemistry and has taught at both Harvard University and the Massachusetts Institute of Technology in Cambridge. He took pains to ensure that the voices in the opera have appropriately matched scents. For example, the fragrance of one character, Crunchy Green, is made up of ingredients that include a leafy-smelling chemical and a rooty scent known as gentian absolute, derived from gentian plants that grow on dormant volcanoes in France.

The unconventional music of the opera written by composers Nico Muhly and Valgeir Sigurðsson - does not contain words but consists instead of sung sounds, notes played by orchestra instruments and electronic elements. When the music calls for a chord of voices, the scent speakers, too, release a 'chord' of corresponding odours.

Laudamiel notes that the team had to consider human biology when constructing the piece. Specifically, the succession of sounds and scents needed careful arrangement - a person can quickly become accustomed to one scent, such that it loses its impact if there is no variation. Moreover, "the perception of scent number two is going to depend on scent number one", he adds.

Stewart doesn't bar the possibility of someday wearing one of the scents developed for Green Aria in public, but explains that they would need fine-tuning. "The intent is to compose the scents for the opera. If there is a potential to apply the scents to the skin, that's a secondary consideration."

Roxanne Khamsi is news editor for Nature Medicine in New York. 